\title{
JOURNAL.RU
}

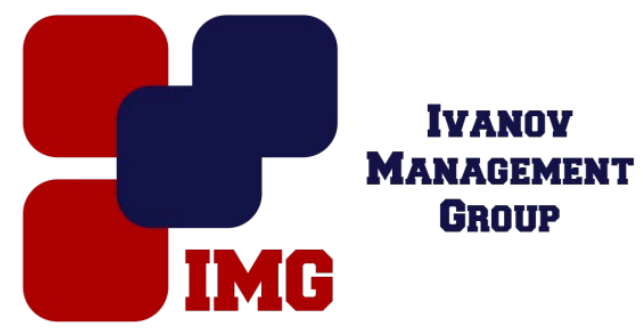

Власова Е.И. НИУ БелГУ Белгород, Россия

doi: 10.18411/lj-30-11-2016-2-03

idsp 000001:lj-30-11-2016-2-03

\section{Женщины в жизни Александра II: Супруга Мария Александровна}

Александр II пользовался большим успехом у женщин, но главной, на наш взгляд, в его жизни были супруга Мария Александровна.

Принцесса Мария родилась 27 июля (8 августа) 1824 года в семье герцога Людвига II Гессенского. В марте 1839 года, путешествуя по Европе, наследник российского престола, сын императора Николая I Александр, будучи в Дармштадте, влюбился в 14-летнюю Марию. Первая встреча цесаревича и принцессы произошла в оперном театре, где шла постановка «Весталки».

В сентябре 1840 года принцесса прибыла в Россию. Впечатлениями о Санкт-Петербурге она поделилась в письме к родным: «Петербург гораздо красивее, чем я думала; этому много способствует Нева; это чудная река; я думаю, трудно найти более величественный город: при этом он оживлён; вид из Зимнего дворца на Неву исключительно хорош».

5 (17) декабря 1840 года принцесса приняла православие с именем «Мария Александровна».

«На следующей день, 6 декабря, было обручение цесаревича с великой княжной Марией Александровной. С той же торжественностью и роскошью был парадный выход. Обручение свершилось в присутствии всей царской фамилии, всего двора, всей российской знати и множества знатных иностранных гостей, и представителей иностранных государств».

16 (28) апреля 1841 года в Соборной церкви Зимнего дворца состоялось бракосочетание.

Фрейлина Тютчева так описывает Марию Александровну: «Я сказала, что, когда я впервые увидела великую княгиню, ей было уже 28 лет. Тем не менее она выглядела еще очень молодой. Она всю жизнь сохранила эту молодую наружность, так что в 40 лет её можно было принять за женщину лет тридцати. Несмотря на высокий рост и стройность, она была такая худенькая и хрупкая, что не производила на первый взгляд впечатление belle femme[красавицы]; но она была необычайно изящна, тем совершенно особым изяществом, какое можно найти на старых немецких картинах, в мадоннах Альбрехта Дюрера...<...> Черты её не были правильны. 
Прекрасны были её чудные волосы, её нежный цвет лица, её большие голубые, немного навыкат, глаза, смотревшие кротко и проникновенно. Профиль её не был красив, так как нос не отличался правильностью, а подбородок несколько отступал назад. Рот был тонкий, со сжатыми губами, свидетельствовавший о сдержанности, без малейших признаков способности к воодушевлению или порывам, а едва заметная ироническая улыбка представляла странный контраст к выражению её глаз. Я настаиваю на всех этих подробностях потому, что я редко видала человека, лицо и наружность которого лучше выражали оттенки и контрасты его внутреннего чрезвычайно сложного я».

По воспоминаниям современников Мария Александровна обладала исключительной добротой, искренностью и вниманием к людям. Она была очень набожна и строго соблюдала церковные догматы. У императрицы было очень развито чувство долга. «Это прежде всего была душа чрезвычайно искренняя и глубоко религиозная, но эта душа, как и её телесная оболочка, казалось, вышла из рамки средневековой картины....Душа великой княгини была из тех, которые принадлежат монастырю. <..> Вот подходящая обстановка для этой души, чистой, сосредоточенной, неизменно устремленной ко всему божественному и священному, но не умевшей проявить себя с той горячей и живой отзывчивостью, которая сама и дает и получает радость от соприкосновения с людьми».

Цесаревич Александр (будущий император Александр II) так представлял свою невесту её будущему законоучителю Г. Т. Меглицкому: «Его Высочество изволил обратить внимание на Её Высочество, и сказать, что я найду в ней самую невинную душу, готовую к принятию всякого добра».

Сестра Александра II Ольга писала: «Мари не хватало мягкости и привлекающей к себе сердечной веселости. Было только немного людей, которые сумели к ней приблизиться. <..> Вообще она считалась женщиной большого сердца и чувства, но её улыбка все чаще была грустной».

Историк, правовед К. Д. Кавелин, который преподавал историю цесаревичу Николаю Александровичу, пишет об общем впечатлении «застенчивости и робости», которое возникло у него при встрече с императрицей в 1857 г. «Намерения и чувства, без сомнения, - самые лучшие, но в мыслях видна нетвёрдость, неясность, нерешительность, которые характеризуют жертву событий, а не владычицу их».

Адмирал Д. С. Арсеньев, который был воспитателем ее младших сыновей, пишет: «императрица жила только для исполнения своей высокой обязанности (Императрицы, супруги и матери), чуждая всякой суетности и мелкой жизни, была к себе самой очень строга, но в отношении к своему супругу и своим детям думала, что нельзя требовать от других такого возвышенного и строгого взгляда на жизнь».

Военный министр Д. А. Милютин пишет об императрице « <..>[она] внушила мне чувство благоговейного почтения. Это была святая женщина в нравственном отношении и вместе с тем высокого ума и образования».

Король Баварии Людвиг II писал, что императрица Мария Александровна, которая гостила в его замке Берг в 1868 г., «осенена ореолом святой».

В России Мария Александровна скоро стала известна широкой благотворительностью - мариинские больницы, гимназии и приюты были 
весьма распространены и заслужили высокую оценку современников. Всего она патронировала 5 больниц, 12 богаделен, 36 приютов, 2 института, 38 гимназий, 156 низших училищ и 5 частных благотворительных обществ - все они требовали от великой княгини неусыпного внимания. На них Мария Александровна тратила и государственные деньги, и часть своих средств, ведь ей выделялись на личные расходы 50 тысяч рублей серебром в год. Она оказалась человеком глубоко религиозным и, по свидетельству современников, ее легко можно было представить в монашеской одежде, безмолвную, изнуренную постом и молитвой. Впрочем, для будущей императрицы такую религиозность вряд ли можно было считать достоинством. Ведь ей приходилось выполнять многочисленные светские обязанности, а чрезмерная религиозность приходила с ними в противоречие.

Императрица была умна и легко ориентировалась в правительствующих делах мужа. Доверие императора к супруге вызвало ревность его ближайшего окружения (к тому же оно было слишком не похоже на отношения между Николаем Павловичем и Александрой Федоровной), и придворные начали нашептывать ему, что по Петербургу ходит слух, будто Мария Александровна им руководит, а значит, является соправителем государства. Этот шепоток упал на подготовленную почву, с детских лет предположение о том, что он может быть чьим-то «ведомым», было наиболее обидным для Александра Николаевича. Слух же о том, что он находится «под каблуком» у жены, оскорбителен не только для монарха, но и для всякого взрослого мужчины (совершенно не важно при этом, справедлив подобный слух или нет). Не удивительно, что государь вскоре перестал говорить с императрицей о делах и вообще начал обходиться с ней довольно холодно. Отныне, если она хотела за кого-нибудь похлопотать, то вынуждена была обращаться к министрам, у мужа еe просьбы вызывали лишь резкую отповедь.

Супругам пришлось пережить вместе немало тяжелых минут, даже потрясений (так, в 1849 году умер первый ребенок Александра и Марии, дочь Александра), но испытания до поры только сближали великокняжескую чету. Переломным моментом, неким водоразделом в их отношениях стала, по мнению большинства современников и исследователей, болезнь и внезапная смерть наследника престола, великого князя Николая Александровича. Он заболел вследствие то ли падения с лошади, то ли от удара об угол мраморного стола во время шутливой борьбы с принцем Лейхтенбергским.

Александру же Николаевичу не давало покоя сознание того, что, быть может, именно он стал невольной причиной болезни цесаревича. В детском возрасте наследник был хрупким, чересчур изнеженным ребенком, и чтобы исправить этот недостаток, отец приказал ему усиленно заниматься физическими упражнениями, что привело, пусть и случайно, к печальному исходу. А ведь речь шла не только о жизни цесаревича. Император видел, как в результате разворачивающихся событий ухудшалось здоровье и Марии Александровны. Кроме того, как мы уже отмечали, наследник престола - это не просто царский сын, это человек, определенным образом подготовленный к занятию трона, в конце концов, человек, избранный на этот пост Богом. 11 апреля 1865 года Александра Николаевича разбудили в шесть часов утра и 
доложили, что «цесаревич слабеет». В тот же день Николай Александрович умер.

Роковое для жизни императрицы впечатление произвели на нее и измена мужа (о которой речь, как мы и обещали пойдет ниже), и многочисленные покушения народников-террористов на его жизнь. В своей сумме эти события не позволили ей ни оправиться от болезни, ни забыть о бедах и горестях, свалившихся на ее плечи. Ей ничего не оставалось, как только повторить что-то вроде: «Больше незачем жить, я чувствую, что это меня убивает... Знаете сегодня убийца (А. К. Соловьев - Л. Л.) травил его как зайца. Это чудо, что он спасся». К 1880 году Мария Александровна превратилась в собственную тень или, как предпочитали выражаться придворные, «стала воздушной». Она вставала только затем, чтобы совершить утренний туалет, и изредка поднималась к обеду в кругу семьи. 17 февраля 1880 года у нее случился очередной приступ болезни, который оказался настолько силен, что императрица впала в летаргическое состояние и даже не слышала взрыва, произведенного в Зимнем дворце Степаном Халтуриным. Иными словами, с середины 1860-х годов жена физически не могла в полной мере оставаться опорой, помощницей и утешительницей императора. 22 мая 1880 года Мария Александровна скончалась. Незадолго до этого она попросила, чтобы ей дали умереть в одиночестве. «Не люблю я этих пикников возле смертного одра», - так больная в последний раз выразила свою приверженность к уединению и покою, которых она была столь долго лишена.

В июле того же года, не дожидаясь окончания положенного траура в один год, Александр II заключил морганатический брак с княжной Долгоруковой, что было ударом для его детей от Марии Александровны, которые обожали мать. Дочь императора Мария писала отцу: «Я молю Бога, чтобы я и мои младшие братья, бывшие ближе всех к Мама, сумели бы однажды простить Вас».

Менее чем через год (1 марта 1881 года) Александр II был убит «народовольцами». Похоронили императора в Петропавловском соборе рядом с первой женой. Места захоронения Александра II и Марии Александровны отличаются от других тем, что надгробия, установленные по решению их сына Александра III, выполнены из яшмы и орлеца. 


\section{Литература}

1. Арсеньев, Д.С. Из воспоминаний генерал-адъютанта адмирала Д. С. Арсеньева. 1876-1878. / Д.С. Арсеньев. // «Русский архив», № 12. — М.: Печать, 1911.

2. Бертенсон, И. В. Императрица Мария Александровна в её заботах о деятельности Российского общества Красного Креста. / И.В. Бертенсон. // Русская старина. - №1. - М.: Наука, 1892. - 165 с.

3. Зимин, И. Взрослый мир императорских резиденций. Вторая четверть XIX - начало XX в.. / И. Зимин. - М.: Центрполиграф, 2011. - 560 с.

4. Кавелин, К.Д. Из дневника 1857 г. / К.Д. Кавелин. - СПб.: Питер, 1898. $1258 \mathrm{c}$.

5. Каратыгин, П.П. Императрица Мария Александровна, 1824-1880. / П.П. Каратыгин. - СПб: Типография В.С. Балашева, 1881. - 250 с.

6. Маркелов, И.И. Воспоминания 1839 г. Первая встреча императора Александра II и императрицы Марии Александровны. / И.И. Маркелов. // Русская Старина, №4. - 1898. - С. 19-22

7. Меглицкий, Г. Т. Письмо к А. И. Голубовой / Г.Т. Меглицкий. // Исторический вестник, 1891. - Т. 43. - № 1. - С. 282-286.

8. Милютин, Д.А. Дневники 1873-1882 в 4 т. / Д.А. Милютин. - М.: Печать, 1947. - $436 \mathrm{c.}$

9. Николай I. Манифест. О обручении Его Императорского Высочества Государя Наследника Цесаревича, Великого Князя Александра Николаевича с Светлейшею Принцессою Мариею, Дочерью Великого Герцога Гессен-Дармштадтского // Полное собрание законов Российской империи. Собрание второе. - СПб.: Типография II отделения Собственной Его Императорского Величества канцелярии, 1841. - T. XV, отделение первое, 1840, № 14024. - С. 784.

10. Петрова, Т.А. Комнаты императрицы Марии Александровны в Зимнем Дворце. / Т.А. Петрова. - СПб: Государственный Эрмитаж, 2007. - 72 с.

11. Сон юности. Воспоминания великой княжны Ольги Николаевны. 18251846. // Николай І. Муж. Отец. Император. - Спб.: Исторический вестник, 2000. - 309 c.

12. Тютчева, А. Ф. При дворе двух императоров. Воспоминания и фрагменты дневника фрейлина двора. / А.Ф. Тютчева. - М.: Печать, 1990. - 281 с.

13. Яковлева, А. И. Воспоминания бывшей камер-юнгеферы императрицы Марии Александровны. / А.И. Яковлева. // Исторический вестник, 1888. T. 31. — № 1. - C. 147-174 